\title{
New species of Luxemburgia A. St.-Hil. (Ochnaceae) ${ }^{1}$
}

\author{
FABÍOLA FERES ${ }^{2,3}$
}

(received: October 21, 2009; accepted: September 21, 2010

\begin{abstract}
New species of Luxemburgia A. St.-Hil. (Ochnaceae)). Three new species of Luxemburgia named as L. furnensis Feres, L. leitonii Feres and L. mogolensis Feres are described and illustrated. A map with the geographical distribution of the new species is provided. Luxemburgia furnensis and L. polyandra A.St.-Hil., both from Minas Gerais, are similar in the absence of cilia on the leaf margin, but L. furnensis differs in the leaf shape, inflorescence and flowers size. Luxemburgia leitonii (also from Minas Gerais) differs from L. macedoi Dwyer (from Goiás) by the smaller flowers and absence of cilia at the margins of the bracts and bracteoles. Luxemburgia mogolensis (from Minas Gerais) resembles L. glazioviana (Engl.) Beauverd (from Rio de Janeiro) in the leaf, bracts and bracteoles shape, and differs by the presence of cilia at the sepals.
\end{abstract}

Key words - Campo rupestre vegetation, Minas Gerais, taxonomy

RESUMO - (Novas espécies de Luxemburgia A. St.-Hil. (Ochnaceae)). São descritas e ilustradas três novas espécies do gênero Luxemburgia, denominadas de L. furnensis Feres, L. leitonii Feres e L. mogolensis Feres. É apresentado um mapa com a distribuição geográfica das novas espécies. Luxemburgia. furnensis e L. polyandra A.St.-Hil., ambas de Minas Gerais, são semelhantes quanto à ausência de cílios na margem foliar, mas L. furnensis difere quanto à forma da lâmina foliar e tamanho da inflorescência e flores. Luxemburgia leitonii (de Minas Gerais) difere de L. macedoi Dwyer (de Goiás) pelas flores menores e ausência de cílios na margem das brácteas e bractéolas. Luxemburgia mogolensis (de Minas Gerais) assemelha-se a L. glazioviana (Engl.) Beauverd (do Rio de Janeiro) na forma das folhas, brácteas e bractéolas, e difere pela presença de cílios nas sépalas.

Palavras-chave - Campos rupestres, Minas Gerais, taxonomia

\section{Introduction}

Luxemburgia A. St.-Hil. is an exclusively Brazilian genus of the Ochnaceae family. The species of Luxemburgia are shrubs with yellow flowers and occur in the campo rupestre vegetation of Brazil, in mountains above 1,000 $\mathrm{m}$ a.s.1. They are found primarily in Minas Gerais, but also in Bahia throughout the Espinhaço Range, in Goiás, Rio de Janeiro (Feres 2001), and Espirito Santo (Fraga \& Feres 2007).

Luxemburgia was described as a genus of Frankeniaceae by Saint-Hilaire (1822), who dedicated the genus to the Duke of Luxemburg, Ambassador of France to Rio de Janeiro. The taxonomic review of the genus was performed about 50 years ago (Dwyer 1951), and was out of date (Feres 2001). Since then, new species were described (Dwyer 1955, Sastre 1981, Fraga \& Feres 2007). Recently the genus has been treated in local florulas, such as Azevedo (1994), for the Reserva Ecológica of Macaé de Cima, Rio de Janeiro, Sastre (1995), for the Flora of Pico das Almas, Bahia,

\footnotetext{
1. Part of the first author's MSc Dissertation, Programa de PósGraduação em Biologia Vegetal of Universidade Estadual de Campinas, Campinas, SP, Brazil.

2. Universidade Estadual de Campinas, Instituto de Biologia, Departamento de Botânica, Caixa Postal 6109, 13083-970 Campinas, SP, Brazil.

3. Address for correspondence: fabiola.feres@gmail.com
}

and Yamamoto \& Sastre (2004), for the Flora of GrãoMogol, Minas Gerais. In this work, three new species of Luxemburgia are described, commented and illustrated. A map with the geographical distribution of the new species is presented.

\section{Materials and methods}

The taxonomic review of the genus Luxemburgia (Feres 2001), was based on a bibliographic review, field observations and collection of specimens, and analysis of herbarium specimens (including type specimens) from ESA, F, HB, HUEFS, IAN, INPA, K, M, MBM, MO, NY, PARNASO, R, RB, SP, SPF, UB, UEC, and US. During this study, new species for Luxemburgia were recognized and they are described below.

\section{Results and discussion}

Luxemburgia furnensis Feres sp. nov. Type: BRAZIL. Minas Gerais: Passos, Reserva de Furnas, em afloramento rochoso próximo à entrada das eclusas, $500 \mathrm{~m}$ após a barragem da usina,1-III-1999, F. Feres, S. Crespo \& R. Belinello 99/01 (holotype UEC; isotypes F, NY, R, SP, SPF).

Figure 1

Luxemburgiae polyandrae A. St.-Hil. longitudine petioli et sepalis eciliatis similis sed lamina majore 


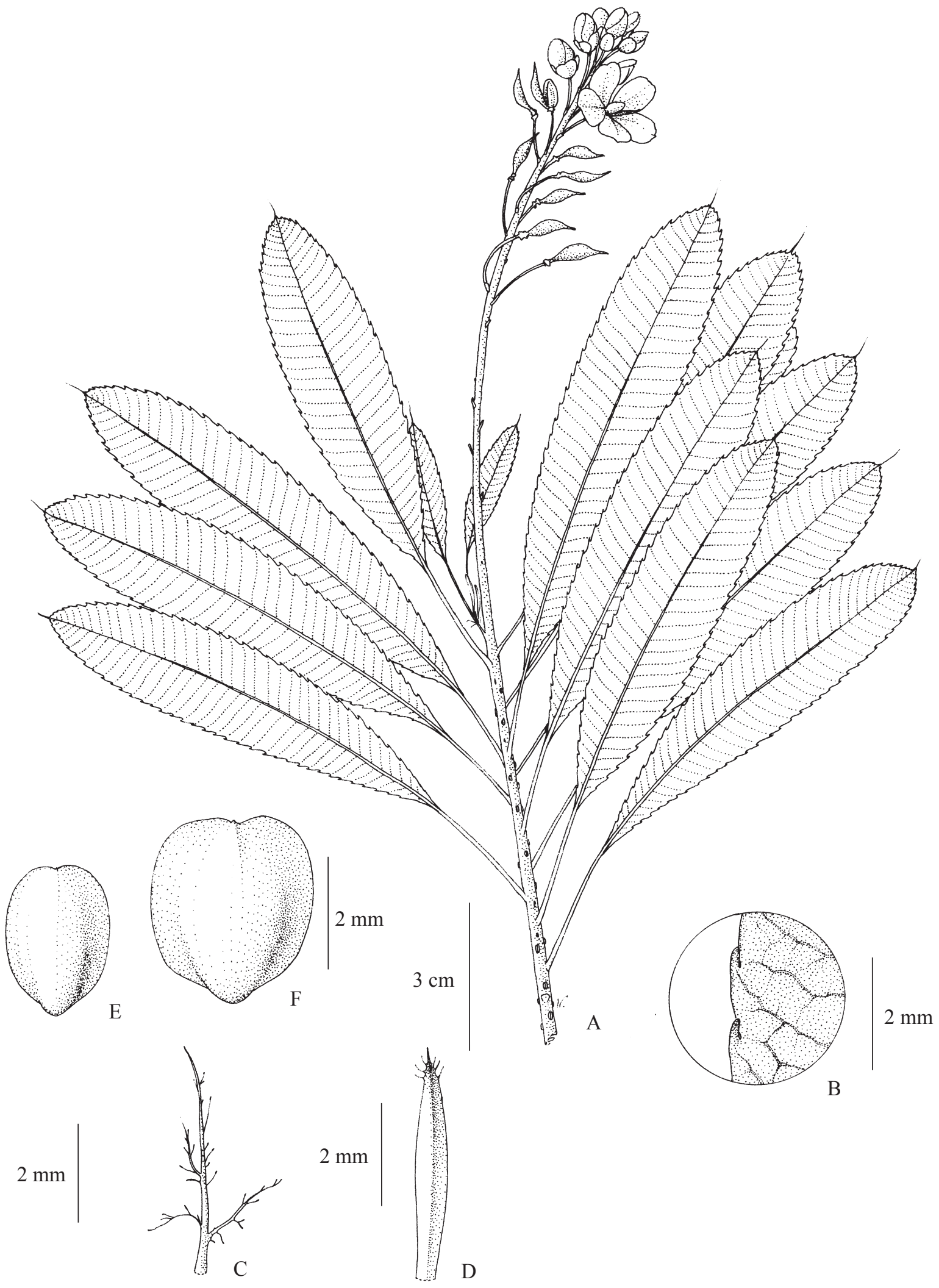

Figure 1. Luxemburgia furnensis Feres. A. Flowering branch. B. Detail of leaf margin, abaxial side. C. Stipule. D. Bracteole. E. Outer sepal. F. Inner sepal. (Feres et al. 99/01). 
$5-15 \times 1.2-3.2 \mathrm{~cm}$, oblonga vel elliptica numquam obovata, inflorescentia majore 1-11 × 15-25 cm, floribus majoribus $2-5 \mathrm{~mm}$, calyce recto numquam reflecto differt; $a b$ Luxemburgia macedoi Dwyer bracteis et bracterolis eciliatis, articulo pedicelli $3 \mathrm{~mm}$ supra basem differt.

Shrub 0.8-2(-3) $\mathrm{m}$ tall; lenticels $1-4 \mathrm{~mm}$ long, orbicular, oblong to elliptic. Stipules $4-5 \mathrm{~mm}$ long, caducous, dissected, often reddish. Petiole $0.8-2 \mathrm{~cm}$ long, glabrous; lamina 5-15 × 1.2-3.2 cm, coriaceous, oblong to elliptic, apex obtuse, acute to acuminate, apical cilium 3-6 mm long, base cuneate to slightly asymmetric, margin toothed, teeth 1-2 mm long, uncinate, rarely ciliate, when present the cilia $0.5-1 \mathrm{~mm}$ long, laterally emergent on the lamina, midrib prominent on both sides, secondary veins prominent on the adaxial side and plane on the abaxial side. Inflorescence 15-25 cm long, 20-45-flowered, bracts and bracteoles 3-5 $\times 1 \mathrm{~mm}$, caducous, narrowly oblong to lanceolate, apex 5-8-ciliate, cilia $0.2-0.5 \mathrm{~mm}$ long, or only 1 terminal cilium present, margin not ciliate; pedicel $0.5-1.5 \mathrm{~cm}$, articulated $1-2(-3) \mathrm{mm}$ from the base. Outer sepals (2-)2.5-4 $\times 2-3 \mathrm{~mm}$, inner sepals (3-)4-6 × 3-4 mm, orbicular to obovate, apex obtuse or retuse, margin not ciliate; petals $1.2-1.7 \times 0.9-1 \mathrm{~cm}$, obovate, apex rounded to retuse; stamens 18-27, arranged in 3-4 series, anthers 5-7 $\times 1 \mathrm{~mm}$; ovary 4-5 $\times 2 \mathrm{~mm}$, style 2-3 $\times 0.5-1 \mathrm{~mm}$, suberect. Capsule 1.2-2 $\times 0.5-0.8 \mathrm{~cm}$, oblong to elliptic (mature). Seeds 1-1.5 $\times 0.5-0.8 \mathrm{~mm}$, oblong to obovate.

Paratypes: BRAZIL. Minas GeraIs: Alpinópolis, way to Morro do Chapéu, $20^{\circ} 52^{\prime} \mathrm{S}, 4^{\circ} 24^{\prime} \mathrm{W}$, 12-II-1998, R. Goldenberg et al. 464 (UEC); Passos, Reserva de Furnas, 03-VII-1994, J.A. Lombardi 583 (UEC), 13-II-1998, R. Romero et al. 5127 (UEC), 2-III-1984, S.J Santi \& D. Santos Filho 15895 (UEC), 20-II-1978, G.J. Shepherd et al. 7008 (HUEFS, UEC).

Distribution, habitat and phenology - Luxemburgia furnensis occurs in campo rupestre vegetation in Minas Gerais. This species is mainly found at Furnas Power Plant Reserve in Passos, but was also collected in Alpinópolis, Minas Gerais (Figure 2). It has been collected with flowers from February to March, and with fruits from March to July.

This species has often been incorrectly identified as Luxemburgia polyandra A. St.-Hil., that occurs in Diamantina, Minas Novas, Rio Vermelho and Serra do Cipó (Minas Gerais), because both have petioled leaves, rarely ciliate on the margin. However, L. furnensis is distinguished by its oblong or elliptic lamina, which in

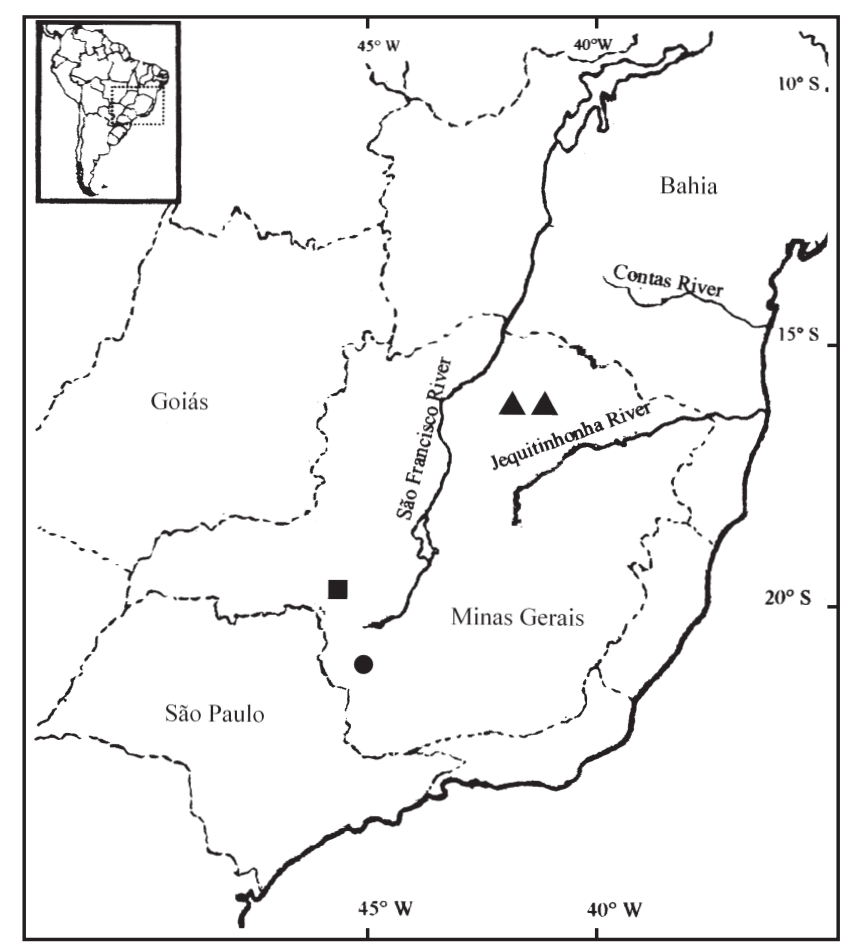

Figure 2. Geographical distribution of Luxemburgia furnensis Feres (•), L. leitonii Feres ( $\bullet$ ), and L. mogolensis Feres ( $\mathbf{\Delta}$ ) in Minas Gerais State.

L. polyandra is generally obovate. Besides, L. polyandra has smaller inflorescences $(7-14 \mathrm{~cm})$ and flowers with reflexed sepals.

One of the remarkable characteristics of this new species is the presence of cilia only at the bracts and bracteoles apex, differing from L. polyandra and from the majority of the species of the genus. Luxemburgia flexuosa Sastre, from Diamantina and Serra do Cipó (Minas Gerais), also has bracts and bracteoles without cilia on the margins, bearing only a cilium at the apex, and differs from L. furnensis by its sessile leaves, the persistent and subulate stipules, whereas in L. furnensis the leaves are distinctly petioled and the stipules are caducous and dissected.

Luxemburgia furnensis resembles $L$. macedoi Dwyer, from Goiás, because of the oblong to elliptic shape of the leaves and the size of the flowers, but differs by the presence of cilia only at the apex of the bracts and bracteoles, absence of cilia on the sepals margins, and also by the articulation of the pedicel, only $3 \mathrm{~mm}$ from the base, while in L. macedoi the articulation is located ca. $5 \mathrm{~mm}$ from the base of the pedicel.

The new species is being named in reference to the main locality of its occurence, the Furnas Power Plant Reserve, in Passos, Minas Gerais. 
Luxemburgia leitonii Feres sp. nov. Type: BRAZIL. Minas Gerais: Araxá, campo rupestre da Serra da Canastra, 5-XII-1977, H.F. Leitão-Filho, J.B. de Andrade \& G. Bunfarah 6589 (holotype UEC, isotype RB). Figure 3

Luxemburgiae macedoi Dwyer forma oblonga et magnitude foliorum 5-10.5 × 1.5-3.5 cm, margine laminae dentibus uncinatisque similis, sed pedicellis parvis 1-2.5 cm, marginibus bractearum et bracteolarum eciliatis differt; $a b$ Luxemburgia furnensis Feres petiolo breve, bracteis et bracteolis in apice nonnisi cilio unico differt. Ab omnibus speciebus generis inflorescentiis usque $50 \mathrm{~cm}$ longis, 40-80-floris differt.

Shrub up to $0.8 \mathrm{~m}$ tall; lenticels $1-5 \mathrm{~mm}$ long, narrowly elliptic. Stipules $4-10 \mathrm{~mm}$ long, caducous, dissected. Petiole 0.3-1 cm long; lamina $5-10.5 \times 1.5-3.5 \mathrm{~cm}$, coriaceous, elliptic, oblong to obovate, apex obtuse to acute, apical cilium 3-5 mm long, marginal teeth 2-3 mm long, uncinate to erect, rarely ciliate, when present, cilia 1-2 mm long near the lamina base, midrib prominent near the base and plane towards the apex on both sides, secondary veins prominent in both sides. Inflorescence $22-50 \mathrm{~cm}$ long, with 40-80 flowers; bracts and bracteoles 4-5 $\times 1 \mathrm{~mm}$, caducous, linear, apex acuminate, glandular, margin not ciliate; pedicel 1-2.5 cm long, articulated 5-8 mm from the base. Outer sepals $3-5 \times 3 \mathrm{~mm}$; inner sepals 5-6 $\times 3-4 \mathrm{~mm}$, oblong to ovate, occasionally orbicular (outer), apex acuminate, rounded to emarginated, margin not ciliate; petals $1-2 \times 0.8 \mathrm{~cm}$, obovate, apex cuspidate to obtuse; stamens $26-37$, in 3-4 series, anthers 7-8 $\times 0.8-1 \mathrm{~mm}$; ovary 6-8 $\times 1-3 \mathrm{~mm}$, style $2-3 \mathrm{~mm}$ long, suberect. Capsule 1.3-1.7 $\times 0.4-0.6 \mathrm{~cm}$, elliptic to oblong (immature). Seeds $1 \times 0.8 \mathrm{~mm}$, oblong.

Distribution, habitat and phenology - Luxemburgia leitonii occurs in Minas Gerais, in boundary regions with Serra da Canastra, including Araxá (figure 2). It has been collected with flowers and fruits in December. This species is known only from the type collection.

The specimen collected in Araxá resembles very much Luxemburgia macedoi Dwyer, which occurs only in Goiás, in the oblong shape, size 5-10.5 × 1.5-3.5 cm and uncinate teethed margin of the leaves. It differs from L. macedoi by the smallest pedicel of $1-2.5 \mathrm{~cm}$, and the margins of the bracts and bracteole not ciliate. Therefore, the specimen Leitão Filho et al. 6589 is being considered here as belonging to a new species, L. leitonii, named in honour of the collector, the late Prof. Dr. Hermógenes de Freitas Leitão Filho, professor and researcher on
Angiosperm taxonomy, of the Universidade Estadual de Campinas.

This species also resembles L. furnensis Feres, but the petiole is shorter, up to $1 \mathrm{~cm}$ long, the bracts and bracteoles are glabrous and with an acuminate apex, while L. furnensis has up to 8 cilia on the apex of the bracts and bracteoles. In L. leitonii the secondary veins are prominent on the abaxial side of the leaf, while in L. furnensis the secondary veins are plane.

The most remarkable characteristics observed in Luxemburgia leitoni, and not seen in other species of the genus, is the inflorescence length, which can reach $50 \mathrm{~cm}$, and the number of flowers per inflorescence, that can be up to 80 .

This species is probably restricted to boundary regions of the Serra da Canastra (figure 2). In the study of endemic plant species of the Parque Nacional da Serra da Canastra (Romero \& Nakajima 1999) there is no record for Luxemburgia species.

Luxemburgia mogolensis Feres sp. nov. Type: BRAZIL. Minas Gerais: Grão-Mogol, Trilha da Tropa, $16^{\circ} 35^{\prime}$ S, 4254' W, ca. 1000-1200 m, 11-XII-1989, A. FreireFierro, J.R. Pirani, P.T. Sano \& T.R. Silva 12462 (holotype UEC, isotype SPF).

Figure 4

Luxemburgiae glaziovianae (Engl.) Beauverd forma foliorum oblongis, bractearum et bracteolarum similis, sed sepalis ciliatis, ciliis margine foliari emergentibus, nervis secundariis in pagina foliari abaxiali differt.

Shrub 1.5-2(-4) m tall; lenticels 1-3 mm long, oblong to elliptic. Stipules 2-4 mm long, caducous, dissected. Petiole 1.2-3 cm long, glabrous; lamina 4-9 × 1.3-3 cm, chartaceous, oblong to obovate, apex acute to acuminate, apical cilium 4-10 mm long, base cuneate to slightly asymmetric, margin toothed, teeth 1-1.5 mm long, uncinate, all ciliate, cilia 60-90 of 3-5 mm long, emergent exactly on the margin, midrib prominent on both sides, secondary veins prominent on adaxial side and plane on abaxial side. Inflorescence 8-16 cm long, with 32-40 flowers; bracts and bracteoles 5-8 $\times 1-1.5 \mathrm{~mm}$, caducous, lanceolate to narrowly oblong, margin ciliate, except at the base; cilia $\mathrm{ca}$. 17, 1-2 mm long; pedicel 1-2 cm long, articulated $c a$. 1-3 $\mathrm{mm}$ from the base. Outer sepals 5-6 $\times 4-6 \mathrm{~mm}$, inner sepals 6-7 $\times 5-7 \mathrm{~mm}$, ovate to orbicular (outer) and obovate (inner), apex cuspidate, with glandular apiculus $0.5-1 \mathrm{~mm}$ long, margin ciliate, except at the base, cilia $c a$. 30, 1-2 mm long; petals 0.9-2 $\times 0.8-1 \mathrm{~cm}$, obovate to oblong, apex cuspidate, with glandular apiculus ca. $0.5 \mathrm{~mm}$ long; stamens $28-32$, 


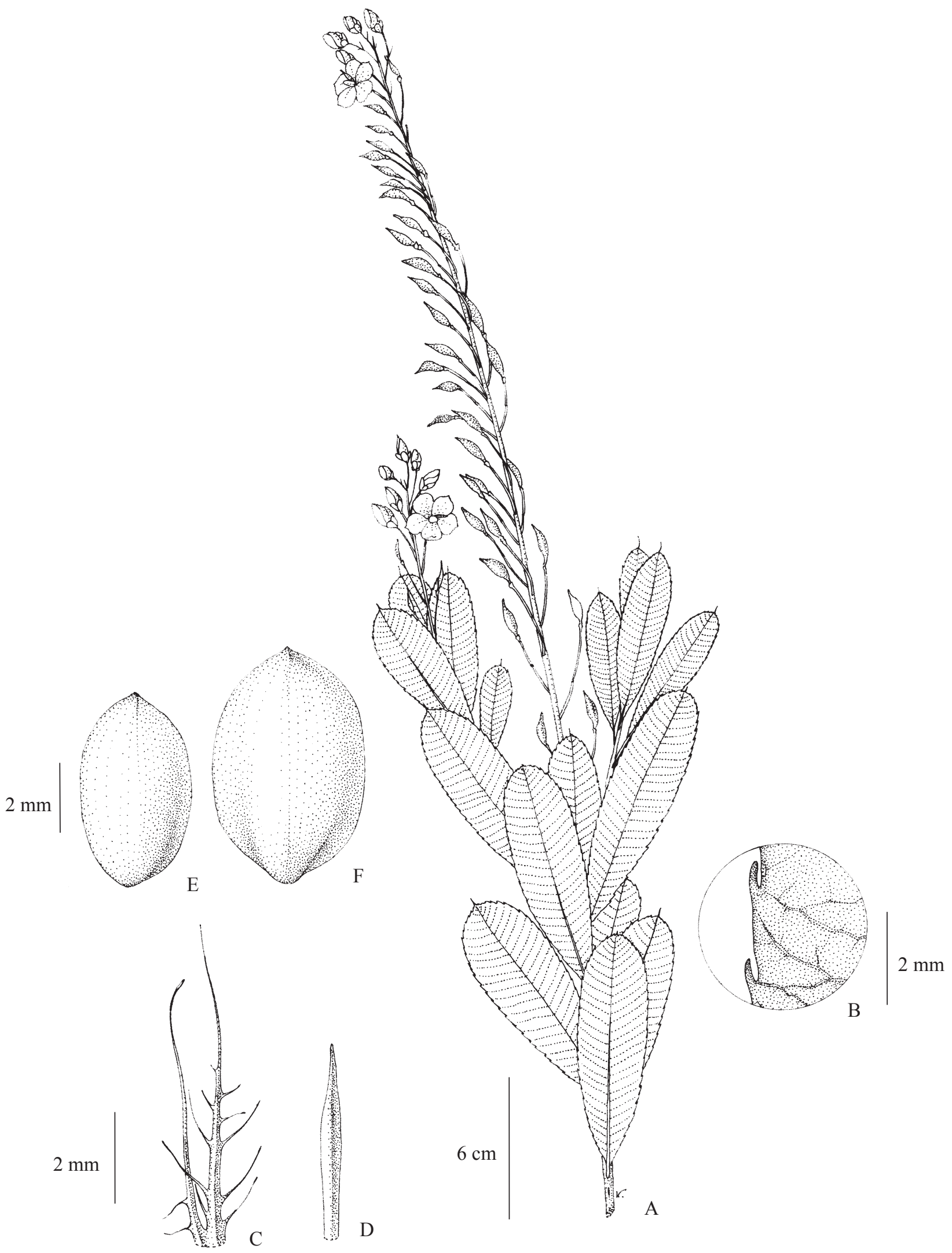

Figure 3. Luxemburgia leitonii Feres. A. Flowering branch. B. Detail of leaf margin, adaxial side. C. Stipule. D. Bracteole. E. Outer sepal. F. Inner sepal. (Leitão Filho et al. 6589). 


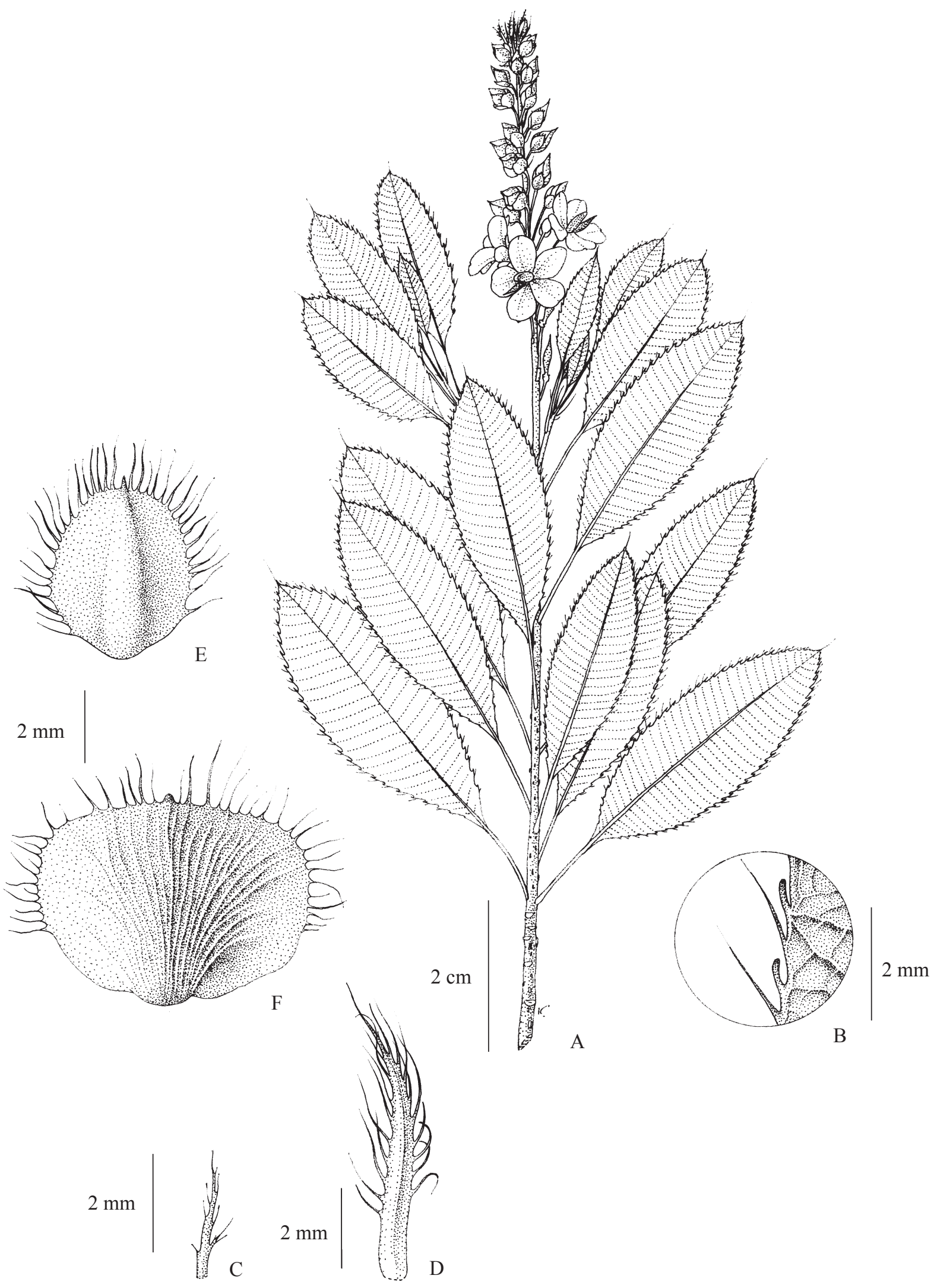

Figure 4. Luxemburgia mogolensis Feres. A. Flowering branch. B. Detail of leaf margin, adaxial side. C. Stipule. D. Bracteole. E. Outer sepal. F. Inner sepal. (A-C: Freire-Fierros et al. 12462; D-F: Harley et al. 6511). 
arranged into 4-5 series, anthers 4-7 $\times 0.8-1 \mathrm{~mm}$; ovary 4-6 $\times 2-3 \mathrm{~mm}$, style 2-4 mm long, suberect. Capsule $1-1.5 \times 0.5-0.7 \mathrm{~cm}$, oblong (mature). Seeds $2 \times 1 \mathrm{~mm}$, oblong.

Paratypes: BRAZIL. Minas Gerais: Cristália, Morro do Chapéu, 1643' S, 4251'W, 6-I-1986, J.R. Pirani et al. CFCR 8897 (F, SPF); Grão-Mogol, $16^{\circ} 35^{\prime}$ S, 42 54 ' W, 27-XI-1984, R.M. Harley et al. CFCR 6511 (UEC); 12-XI-1938, F. Markgraff et al. 3481 (R, RB); trilha dos Garimpeiros, 12-II-1991, G. Hatschbach \& O.S. Ribas 55087 (MBM); Itacambira, $17^{\circ} 00^{\prime}$ S, 5350' W, 9-I-1986, J.R. Pirani et al. CFCR 9114 (SPF); 14-XII-1989, P.T. Sano et al. CFCR 12759 (UEC).

Distribution, habitat and phenology - Luxemburgia mogolensis is found among rocks in campo rupestre vegetation in the Grão-Mogol region, Minas Gerais (figure 2). It has been collected with flowers from November to January, and with fruits from December to January.

Luxemburgia mogolensis is characterized by its oblong to obovate petiolate leaves with toothed and entirely ciliate margins, bracts and bracteoles lanceolate to narrowly oblong, with margins ciliate, except at the base, the outer sepals ovate to orbicular and the inner sepals obovate with the margins ciliate, except at the base.

This species resembles L. glazioviana (Engl.) Beauverd, from Rio de Janeiro, because its oblong to obovate leaves, and bracts and bracteoles lanceolate to narrowly oblong. Because of such similarity, Yamamoto \& Sastre (2004) mentioned the occurrence of $L$. glazioviana in the Flora of Grão-Mogol, Minas Gerais. The analysis of the specimens cited by Yamamoto \& Sastre (2004) revealed that they actually belong to a species distinct to L. glazioviana. In L. glazioviana the sepals are always glabrous whereas in L. mogolensis the sepals are always ciliate, especially the outer ones. Another conspicuous difference between the two species is that in the new species, the marginal cilia of leaves are emergent exactly from the leaf margin, while in $L$. glazioviana the cilia are emergent from the adaxial side of the leaf.

Luxemburgia mogolensis is the northernmost species of the genus in Minas Gerais, and was named after the locality where it is mainly found, Grão-Mogol (figure 2). This area is known for its high levels of endemism in many plant groups (Giulietti \& Pirani 1988, Pirani et al. 2003). The new species proposed here, L. mogolensis, provides another case of endemism for the region of Grão Mogol.

Acknowledgments - The author are most grateful to Maria do Carmo Estanislau do Amaral and Volker Bittrich for many helpful suggestions during the development of this work. To Fapesp for financial support. To Eduardo Kickhöfel, who made the species illustrations. To the Editorial Board and referees, for their valuable comments, essential for the improvement of this work.

\section{References}

AZEVEDO, A.P. 1994. Ochnaeae. In Reserva Ecológica de Macaé de Cima - Nova Friburgo, RJ - Aspectos florísticos das espécies vasculares (M.P.M. Lima \& R.R. Guedes-Bruni, eds.). Jardim Botânico do Rio de Janeiro, Rio de Janeiro, p.309-313.

DWYER, J.D. 1951. The genus Luxemburgia (Ochnaceae). Lloydia 14:82-97.

DWYER, J.D. 1955. Family Ochnaceae. Journal of Washington Academy of Sciences 45:198-199.

FERES, F. 2001. O gênero Luxemburgia A. St.-Hil. (Ochnaceae) - Revisão taxonômica e estudo cladístico. Dissertação de mestrado, Universidade Estadual de Campinas, Campinas.

FRAGA, C.N. \& FERES, F. 2007. Luxemburgia mysteriosa (Ochnaceae), a new species from the Atlantic Rain Forest of Espírito Santo, Brazil. Harvard Papers in Botany 12:405-408.

GIULIETTI, A.M. \& PIRANI. J.R. 1988. Patterns of geographic distribution of some plant species from the Espinhaço Range, Minas Gerais and Bahia, Brazil. In Proceedings of a workshop on Neotropical Distribution Patterns (W.R. Heyer \& P.E. Vanzolini, eds.). Academia Brasileira de Ciências, Rio de Janeiro, p.39-69.

PIRANI, J.R., MELLO-SILVA, R. \& GIULIETTI, A.M. 2003. Flora de Grão-Mogol, Minas Gerais. Boletim de Botânica da Universidade de São Paulo 21:1-25.

ROMERO, R. \& NAKAJIMA, J.N. 1999. Espécies endêmicas do Parque Nacional da Serra da Canastra, Minas Gerais. Revista Brasileira de Botânica 22:259-265.

SAINT-HILAIRE, A. 1822. Aperçu d'un voyage das l'intérieur du Brésil. Mémoires du Muséum d'Histoire Naturelle 9:352.

SASTRE, C. 1981. Ochnaceés nouvelles du Brésil. Bulletin van de Nationale Plantentuin van België 51:397-413.

SASTRE, C. 1995. Ochnaceae. In Flora of the Pico das Almas: Chapada Diamantina, Bahia, Brasil (B.L. Stannard, ed.). Royal Botanical Gardens, Kew, p.519-523.

YAMAMOTO, K. \& SASTRE, C. 2004. Flora de GrãoMogol, Minas Gerais: Ochnaceae. Boletim de Botânica da Universidade de São Paulo 22:343-348. 
